\title{
The Expanding Role of the Oncology Pharmacist
}

\author{
Lisa M. Holle ${ }^{1, * \mathbb{C}}$, Eve M. Segal ${ }^{2}$ and Kate D. Jeffers ${ }^{3}$ \\ 1 School of Pharmacy, University of Connecticut, 69 North Eagleville Road, Storrs, CT 06268, USA \\ 2 Pharmacy Department, Seattle Cancer Care Alliance, Seattle, WA 98109, USA; segaleve@seattlecca.org \\ 3 Pharmacy, UCHealth Southern Colorado Region, Colorado Springs, CO 80909, USA; \\ Kate.Jeffers@uchealth.org \\ * Correspondence: lisa.holle@uconn.edu
}

Received: 13 July 2020; Accepted: 22 July 2020; Published: 25 July 2020

\begin{abstract}
Although oncology pharmacists have been involved in the care of cancer patients for over 50 years, the role of the oncology pharmacist continues to expand. Initially, pharmacists were primarily based within either an inpatient or outpatient pharmacy setting and their work focused on providing the necessary safety checks to dispense cancer-related medications. With technology freeing up pharmacists from dispensing functions and advanced training in direct patient care (e.g., oncology residency, oncology fellowship), the oncology pharmacist was able to provide direct patient care at the bedside or within the clinic where treatment decisions are made by the healthcare team. In fact, they have become integral members of the healthcare team. This Issue describes several expanding roles of oncology pharmacists in stem cell transplant, hematology, gastrointestinal oncology, and precision genomics, as well as oncology pharmacists preventing a reduction in cancer patient visits as the oncology physician shortage occurs. Oncology pharmacists are an integral part of the cancer care team; their value has been documented in several studies, and is highlighted in this Issue. We encourage the profession to continue to document their value so that one day each patient can have an oncology pharmacist as part of their cancer care team.
\end{abstract}

Keywords: hematology/oncology; oncology; pharmacist; pharmacy

Although oncology pharmacists have been involved in the care of cancer patients for over 50 years, the role of the oncology pharmacist continues to expand [1,2]. Initially, pharmacists were primarily based within either an inpatient or outpatient pharmacy setting and their work focused on providing the necessary safety checks to dispense cancer-related medications [2]. With technology freeing up pharmacists from dispensing functions and advanced training in direct patient care (e.g., oncology residency, oncology fellowship), the oncology pharmacist was able to provide direct patient care at the bedside or within the clinic where treatment decisions are made by the healthcare team. In fact, they have become integral members of the healthcare team [3]. With their training and expertise, they can assist with providing evidence-based care to the patient with cancer. Some of their daily responsibilities include educating patients and caregivers about their therapies, improving medication adherence, and educating other members of the healthcare team on medications used in cancer care. Because of their clinical knowledge, literature evaluation skills, and understanding of the complexity of cancer care, they often are involved in the development of guidelines, policies, standards, and clinical pathways both at the institutional level but also at regional, national, and international levels.

Common roles for oncology pharmacists have included inpatient pharmacist, ambulatory pharmacist, infusion center or decentralized pharmacist, specialty pharmacist, practice manager, and investigational drug pharmacist [4]. An inpatient oncology pharmacist typically is responsible for the pharmacotherapy management of patients with cancer while they are hospitalized. They work closely with nursing staff to coordinate chemotherapy administration and provide patient and staff education. The ambulatory 
oncology pharmacist is responsible for medication therapy management for patients with cancer from diagnosis throughout survivorship. They may work under a collaborative practice agreement to prescribe supportive care medications or adjust anticancer medications as well as provide patient education. Infusion center or decentralized oncology pharmacists are involved with the sterile compounding of anticancer treatments and related supportive care medications, and may support some of the direct patient care functions of the ambulatory oncology pharmacists. Specialty oncology pharmacists are involved with distribution and dispensing of oral anticancer treatments. They may work at a specialty pharmacy that is located within the Cancer Center or at an external site, and provide patient education, perform adherence monitoring, and assess patient safety. Oncology practice managers oversee oncology pharmacists, and are often involved in facilitating the ability of the oncology pharmacy team to provide safe and effective care, manage fiscal and personnel resources, develop policies and procedures, and develop strategic quality initiatives. They may also have clinical responsibilities at some institutions. Investigational drug pharmacists are responsible for coordinating the processes related to oncology investigational drug studies in accordance with legal, professional, institutional, and sponsor requirements. Their core responsibility is to ensure the patient's access to investigational drugs and serve as the medication expert to all involved in these research studies. Although these are the most common roles of oncology pharmacists, many other roles exist. These include academia, medical communications, population health management, informatics, companies associated with providing health or pharmacy benefits, manufacturers, wholesalers, and regulatory agencies.

The value of the oncology pharmacist in the care of patients with cancer and within the oncology care team has been documented in several studies [5]. Oncology pharmacists have demonstrated their value in providing clinical care that has directly impacted patient outcomes, supportive care management, laboratory monitoring, and increased documentation in the electronic medical record [6-24]. Patient education, a common component of most oncology pharmacist positions, has been shown to be associated with high rates of patient satisfaction, improved learning outcomes, and leads to increased medication adherence and disease-based outcomes $[6,17,19,25-30]$. Oncology pharmacists have become important members of informatics teams, and their integral role has been shown to be associated with increased rates of medication error identification [9,30,31]. Pharmacist-driven cost-savings have been reported in numerous studies, including those using pharmacists to manage oral anticancer therapies, by providing effective inpatient and ambulatory care and implementing quality improvement programs [18,29,31-37]. Finally, pharmacists can decrease physician and advanced practice provider (APP) time by developing independent practice models and performing tasks typically completed by physicians $[7,31,33,36]$.

A shortage of oncology physicians exists globally, and is expected to continue for several years [38]. Oncology pharmacists are well poised to assist with preventing a reduction in cancer patient visits. In fact, in this Issue of Pharmacy, Knapp and Ignoffo have shown that board certified oncology pharmacists (BCOPs) could contribute to outpatient oncology patient visits, thereby preventing the potential of a shortfall of providers available to care for patients with cancer [39]. With the overlap of clinical activities of BCOPs and APPs, BCOPs may also be able to assist with preventing burnout that often occurs in the oncology healthcare team. Thus, this study demonstrates that improved efficiency and effectiveness of the oncology healthcare team can occur with the expanding role of the oncology pharmacist on care teams.

This journal explores four cases of pharmacists integrating themselves in different care teams, such as stem cell transplant, hematology, gastrointestinal oncology, and precision genomics [40-43]. Some of these clinic activities allow pharmacists to become physician extenders. For example, pharmacogenomic pharmacists are involved in interpreting genomic sequencing reports and subsequently making treatment recommendations [40], whereas other clinics allow pharmacists to practice at the top of their license. In the review by Chen and colleagues [41], pharmacists involved in the management of patients with leukemia can perform independent patient visits and manage patient toxicities related to oral chemotherapy. Furthermore, Darling and colleagues [42] demonstrated that by integrating a 
pharmacist into the oncology care team, patients' understanding of their medication improves, as well as their satisfaction. Lastly, a report by Dr. Clemmons [43] demonstrates that having a pharmacist in stem cell transplant can improve care using collaborative practice agreements.

Oncology pharmacists are an integral part of the cancer care team. They are critical in expanding and enhancing patient care. Their value has been documented in several studies and is highlighted in this Issue. We encourage the profession to continue to document their value so that one day each patient can have an oncology pharmacist as part of their cancer care team.

Author Contributions: Conceptualization, writing—original draft preparation, writing-review and editing, L.M.H., E.M.S., and K.D.J. All authors have read and agreed to the published version of the manuscript.

Acknowledgments: Thank you to Jill Bates, Sara L. Fleszar, Julie Kennerly-Shah, Elizabeth Koselke, Michelle Rockey, and Deborah Ward who previously worked with authors to define the scope of hematology/oncology pharmacy and identified research demonstrating value of the hematology/oncology pharmacist.

Conflicts of Interest: The authors declare no conflict of interest.

\section{References}

1. Carter, B.L. Evolution of clinical pharmacy in the USA and future directions for patient care. Drugs Aging 2016, 33, 169-177. [CrossRef] [PubMed]

2. Hematology/Oncology Pharmacy Association. Scope of Hematology/Oncology Pharmacy Practice [Internet]. Available online: www.hoparx.org/images/hopa/resource-library/professional-tools/HOPA13_ScopeofPracticeBk. pdf (accessed on 5 June 2020).

3. Holle, L.M.; Michaud, L.B. Oncology pharmacists in health care delivery: Vital members of the cancer care team. J. Oncol. Pract. 2014, 10, e142-e145. [CrossRef]

4. Hematology/Oncology Pharmacy Association. Further Defining the Scope of Hematology/Oncology Pharmacy Practice. Available online: http://www.hoparx.org/images/hopa/resource-library/guidelines-standards/HOPA18_ Scope-2_Web2.pdf (accessed on 5 June 2020).

5. Segal, E.-M.; Bates, J.; Fleszar, S.L.; Holle, L.M.; Kennerly-Shah, J.; Rockey, M.; Jeffers, K.D. Demonstrating the value of the oncology pharmacist within the healthcare team. J. Oncol. Pharm. Pract. 2019. [CrossRef] [PubMed]

6. Muluneh, B.; Schneider, M.; Faso, A.; Amerine, L.; Daniels, R.; Crisp, B.; Valgus, J.; Savage, S. Improved adherence rates and clinical outcomes of an integrated, closed- loop, pharmacist-led oral chemotherapy management program. J. Oncol. Pract. 2018, 14, e324-e334. [CrossRef] [PubMed]

7. Alexander, M.D.; Rao, K.V.; Khan, T.S.; Deal, A.M.; Alexander, A.D.; Rao, K.V.; Khan, T.S.; Deal, A.M. ReCAP: Pharmacists' impact in hematopoietic stem-cell trans- plantation: Economic and humanistic outcomes. J. Oncol. Pract. 2016, 12, 147-148; e118-e126. [CrossRef] [PubMed]

8. Battis, B.; Clifford, L.; Huq, M.; Pejoro, E.; Mambourg, S. The impacts of a pharmacist-managed outpatient clinic and chemother- apy-directed electronic order sets for monitoring oral chemotherapy. J. Oncol. Pharm. Pract. 2017, 23, 582-590. [CrossRef]

9. Finn, A.; Bondarenka, C.; Edwards, K.; Hartwell, R.; Letton, C.; Perez, A. Evaluation of electronic health record implementation on pharmacist interventions related to oral chemotherapy management. J. Oncol. Pharm. Pract. 2017, 23, 563-574. [CrossRef]

10. Jackson, K.; Letton, C.; Maldonado, A.; Bodiford, A.; Sion, A.; Hartwell, R.; Graham, A.; Bondarenka, C.; Uber, L. A pilot study to assess the pharmacy impact of implementing a che- motherapy-induced nausea or vomiting collaborative dis- ease therapy management in the outpatient oncology clinics. J. Oncol. Pharm. Pract. 2018, 25, 847-854. [CrossRef]

11. Lucena, M.; Bondarenka, C.; Luehrs-Hayes, G.; Perez, A. Evaluation of a medication intensity screening tool used in malignant hematology and bone marrow transplant services to identify patients at risk for medication-related problems. J. Oncol. Pharm. Pract. 2018, 24, 243-252. [CrossRef]

12. McNamara, E.; Redoutey, L.; Mackler, E.; Severson, J.A.; Petersen, L.; Mahmood, T. Improving oral oncolytic patient self-management. J. Oncol. Pract. 2016, 12, e864-e869. [CrossRef] 
13. Patel, J.M.; Holle, L.M.; Clement, J.M.; Bunz, T.; Niemann, C.; Chamberlin, K.W. Impact of a pharmacist-led oral chemotherapy-monitoring program in patients with metastatic castrate- resistant prostate cancer. J. Oncol. Pharm. Pract. 2016, 22, 777-783. [CrossRef] [PubMed]

14. Ruder, A.D.; Smith, D.L.; Madsen, M.T.; Iii, F.H.K. Is there a benefit to having a clinical oncology pharmacist on staff at a community oncology clinic? J. Oncol. Pharm. Pract. 2011, 17, 425-432. [CrossRef] [PubMed]

15. Shah, N.N.; Casella, E.; Capozzi, D.; Mcgettigan, S.; Gangadhar, T.C.; Schuchter, L.; Myers, J.S. Improving the safety of oral chemotherapy at an academic medical center. J. Oncol. Pract. 2016, 12, e71-e76. [CrossRef] [PubMed]

16. Sweiss, K.; Wirth, S.M.; Sharp, L.; Park, K.; Sweiss, H.; Rondelli, D.; Patel, P.R. Collaborative physicianpharmacist-managed multiple myeloma clinic improves guideline adherence and prevents treatment delays. J. Oncol. Pract. 2018, 14, e674-e682. [CrossRef]

17. Watkins, J.L.; Landgraf, A.; Barnett, C.M.; Michaud, L. Evaluation of pharmacist-provided medication therapy management services in an oncology ambulatory setting. J. Am. Pharm. Assoc. 2012, 52, 170-174. [CrossRef]

18. Whitman, A.; DeGregory, K.; Morris, A.; Mohile, S.; Ramsdale, E. Pharmacist- led medication assessment and deprescribing intervention for older adults with cancer and polypharmacy: A pilot study. Support. Care Cancer 2018, 26, 4105-4113. [CrossRef]

19. Crespo, A.; Tyszka, M. Evaluating the patient-perceived impact of clinical pharmacy services and proactive follow-up care in an ambulatory chemotherapy unit. J. Oncol. Pharm. Pract. 2017, 23, 243-248. [CrossRef]

20. Ho, L.; Akada, K.; Messner, H.; Kuruvilla, J.; Wright, J.; Seki, J.T. Pharmacist's role in improving medication safety for patients in an allogeneic hematopoietic cell transplant ambulatory clinic. Can. J. Hosp. Pharm. 2013, 66, 110-117. [CrossRef]

21. Lopez-Martin, C.; Garrido Siles, M.; Alcaide-Garcia, J.; Felipe, V.F. Role of clinical pharmacists to prevent drug inter- actions in cancer outpatients: A single-centre experience. Int. J. Clin. Pharm. 2014, 36, 1251-1259. [CrossRef]

22. Ramadaniati, H.U.; Lee, Y.P.; Hughes, J.D. The difference in pharmacists' interventions across the diverse settings in a children's hospital. PLoS ONE 2014, 9, e110168. [CrossRef]

23. Suzuki, S.; Chan, A.; Nomura, H.; E Johnson, P.; Endo, K.; Saito, S. Chemotherapy regimen checks performed by pharmacists contribute to safe administration of chemotherapy. J. Oncol. Pharm. Pract. 2017, 23, 18-25. [CrossRef]

24. Suzuki, S.; Sakurai, H.; Kawasumi, K.; Tahara, M.; Saito, S.; Endo, K. The impact of pharmacist certification on the quality of chemotherapy in Japan. Int. J. Clin. Pharm. 2016, 38, 1326-1335. [CrossRef] [PubMed]

25. McKee, M.; Frei, B.L.; Garcia, A.; Fike, D.; Soefje, S.A. Impact of clinical pharmacy services on patients in an outpatient chemo- therapy academic clinic. J. Oncol. Pharm. Pract. 2011, 17, 387-394. [CrossRef] [PubMed]

26. Subongkot, S.; Srisawat, S.; Johns, N.; Sookprasert, A. Outcome of chemotherapy counseling in oncology patients by pharmacist. Isan J. Pharm. Sci. 2009, 5, 34-45.

27. Atreja, A.; Bellam, N.; Levy, S.R. Strategies to enhance patient adherence: Making it simple. Med. Gen. Med. $2005,7,4$.

28. Lam, M.S.; Cheung, N. Impact of oncology pharmacist- managed oral anticancer therapy in patients with chronic myelogenous leukemia. J. Oncol. Pharm. Pract. 2016, 22, 741-748. [CrossRef]

29. Randolph, L.A.; Walker, C.K.; Nguyen, A.T.; Zachariah, S.R. Impact of pharmacist interventions on cost avoidance in an ambulatory cancer center. J. Oncol. Pharm. Pract. 2016, 24, 3-8. [CrossRef]

30. Holle, L.M.; Puri, S.; Clement, J.M. Physician-pharmacist collaboration for oral chemotherapy monitoring: Insights from an academic genitourinary oncology practice. J. Oncol. Pharm. Pract. 2016, 22, 511-516. [CrossRef]

31. Chung, C.; Collins, A.; Cui, N. Development and implementation of an interdisciplinary oncology program in a community hospital. Am. J. Health-Syst. Pharm. 2011, 68, 1740-1747. [CrossRef]

32. Wong, S.-F.; Bounthavong, M.; Nguyen, C.; Bechtoldt, K.; Hernandez, E. Implementation and preliminary outcomes of a comprehensive oral chemotherapy management clinic. Am. J. Health-Syst. Pharm. 2014, 71, 960-965. [CrossRef]

33. Walko, C.; Kiel, P.J.; Kolesar, J. Precision medicine in oncology: New practice models and roles for oncology pharmacists. Am. J. Health-Syst. Pharm. 2016, 73, 1935-1942. [CrossRef] 
34. Amerine, L.B.; Chen, S.-L.; Daniels, R.; Key, N.; Eckel, S.F.; Savage, S.W. Impact of an innovative blood factor stewardship program on drug expense and patient care. Am. J. Health-Syst. Pharm. 2015, 72, 1579-1584. [CrossRef] [PubMed]

35. Reardon, D.P.; Atay, J.K.; Ashley, S.W.; Churchill, W.W.; Berliner, N.; Connors, J.M. Implementation of a hemostatic and antithrombotic stewardship pro- gram. J. Thromb. Thrombol. 2015, 40, 379-382. [CrossRef] [PubMed]

36. Valgus, J.; Jarr, S.; Schwartz, R.; Rice, M.; Bernard, S.A. Pharmacist-led, inter- disciplinary model for delivery of supportive care in the ambulatory cancer clinic setting. J. Oncol. Pract. 2010, 6, e1-e4. [CrossRef]

37. Valgus, J.M.; Faso, A.; Gregory, K.M.; Jarr, S.; Savage, S.; Caiola, S.; Walko, C.M.; Kim, J.; Bernard, S.A.; Campen, C.J.; et al. Integration of a clinical pharmacist into the hematology-oncology clinics at an academic medical center. Am. J. Health-Syst. Pharm. 2011, 68, 613-619. [CrossRef] [PubMed]

38. Mathew, A. Global survey of clinical oncology workforce. J. Glob. Oncol. 2018, 4, 1-12. [CrossRef]

39. Knapp, K.; Ignoffo, R. Oncology pharmacists can reduce the projected shortfall in cancer patient visits: Projections for years 2020 to 2025. Pharmacy 2020, 8, 43. [CrossRef]

40. Raheem, F.; Pauline, K.; Grove, M.; Kiel, P.J. Precision genomic practice in oncology: Pharmacist role and experience in an ambulatory care clinic. Pharmacy 2020, 8, 32. [CrossRef]

41. Chen, K.Y.; Brunk, K.M.; Patel, B.A.; Stocker, K.J.; Auten, J.J.; Buhlinger, K.M.; Muluneh, B. Pharmacist's role in managing patients with chronic lymphocytic leukemia. Pharmacy 2020, 8, 52. [CrossRef]

42. Darling, J.O.; Raheem, F.; Carter, K.C.; Ledbetter, E.; Lowe, J.F.; Lowe, C. Evaluate of a pharmacist led oral chemotherapy clinic: A pilot program in the gastrointestinal clinic at an academic medical center. Pharmacy 2020, 8, 46. [CrossRef]

43. Clemmons, A. The hematopoietic cell transplant pharmacist: A call to action. Pharmacy 2020, 8, 3. [CrossRef] [PubMed]

(C) 2020 by the authors. Licensee MDPI, Basel, Switzerland. This article is an open access article distributed under the terms and conditions of the Creative Commons Attribution (CC BY) license (http://creativecommons.org/licenses/by/4.0/). 